\title{
The Modern Day Culture Hero: From Cynicism to Infernality
}

\author{
Evgenia Vladimirovna Ivanova ${ }^{1} \&$ Valentina Ivanovna Kudriavtseva ${ }^{1}$ \\ ${ }^{1}$ Ural Federal University, Ekaterinburg, Russian Federation \\ Correspondence: Valentina Ivanovna Kudriavtseva, Ural Federal University, Mira Street, 19, Ekaterinburg, \\ 620002, Russian Federation. E-mail: remidosi@gmail.com
}

Received: November 21, 2014 Accepted: December 1, 2014 Online Published: February 25, 2015

doi:10.5539/ass.v11n6p272

URL: http://dx.doi.org/10.5539/ass.v11n6p272

\begin{abstract}
In the paper the reasons of address of the information space's modern religious mythology to infernal cultural heroes through the principle of inversion of moral standards are considered. It is associated with the cynicism phenomenon because cynicism characterizes manipulation by means of reasoning on moral subjects. The purpose of this paper is the analysis of ethical appeal of infernal cultural heroes forming new ethical principles and norms for younger generation. In the paper the review of issues connected with myth-making, with forms of public consciousness in the modern culture is presented. Conclusions about emphasis shift in mass consciousness to positive infernality of the modern cultural hero are drawn.
\end{abstract}

Keywords: myth, religion, myth-making, ethics, morals, cultural hero, cynicism, revaluation of values, mass consciousness

\section{Introduction}

The modern pop culture, cinema, music, images in fiction at the end of XX-the beginning of the XXI century represent a remifologization in the sphere of infernality. The negative connotations existing in archetypic conceptions of witches, vampires, werewolves are endowed with counter meanings, transforming these figures into the modern day cultural heroes." Religious mythology"-new concept, which is demanded by the modern religious studies (Ivanova, 2013). It should be noted that the religion represents the certain world outlook framework recorded in sacral texts (different ones in each religion), and the myth is manifestation of its emotional and ethical contents. The religion orders, sets behavior ideals and the myth emotionally and clearly explains why it is so necessary to do. The myth as illusory consciousness can also have religious coloring and be shown through a genre of a "religious fantasy". Therefore the category "religious mythology" connects two phenomena of spiritual culture in a whole.

Since industrialization led to creation of mass means of communication, speed of information dessimination increased rapidly, the public consciousness began more often to be exposed to transformations under the influence of new mythemes. Researches in the field of media genesis confirmed that "the media culture in the XX century is becoming not only a factor of social modernization, but also a basis for myth-making" (Kirillova, 2005). Active mythologization of motion picture art, television, and also the press takes place.

The product of the modern myth-making shows an unexpected turn to infernality aestheticization. Perhaps, this is consequences of oversaturation of mass consciousness with cynical settings. According to definition of cynicism as the enlightened false consciousness introduced by the German professor of esthetics and philosophy Peter Sloterdijk, cynics are people familiar with the Enlightenment ideals in theory but breaking them in practice (Sloterdijk, 2001). As a result the diffuse cynicism gets into all spheres of human life. Leveling of morals in relation to means takes place, it is reproduced in movies, literature and other creative forms of reflection of reality.

\section{Methodics}

Let us consider the main features of ethical myth-making: 1) Creation by a writer (screenwriter) of his or her own model of the infernal world, however submitting to the common schemes of binarity of the myth. 2) Presence of the romantic line of passionate love of a person (male or female) and an infernal hero: vampire, sorcerer (male or female). 3) Ethical line (fight of good and evil). 4) Religious line (ideas of otherworldly reward, reasoning on wayward soul, "living dead", zombie, necromancers, on the origin of infernal beings). 5) Philosophical and anthropological line (reflections about meaning of life, love, death and immortality, about 
mission of the person in this world). 6) Esthetic line combines the categories of "fine", "ugly", "tragic", "drama", "low", "high" and others. 7) Gender line within the modern female studies. 8) Mythical and historical line (from where infernal beings originate). 9) Secular line-people do not suspect that infernal heroes are near them untill they meet them face to face. 10) Political and legal line-there are the own laws and rules in the infernal world, struggle for power, "punishers", slaves and the slave power and aspiration to release from slave bonds. 11) The line of a "magic fairy tale"-travel across the worlds, dieding and resurrection in a new shape, growing and change of the main character. 12) Humanistic line-the value of the person is emphasized therefore feeding of demonic heroes becomes either "dietary"-they suck blood of animals, or take food from simulated banks of blood, or "have mercy" on donors, without taking their life.

\subsection{Analysis of Mythical Figurativeness}

Feature of mythical figurativeness, as it proves in the modern processes of remifologization, is that it claims on general value, an absolute truth whereas actually displays not communications of the person with the world as a wholeness, but his or her communications with any historical situations. In these situations the border between good and evil, ethical and esthetic, becomes the relative frame, inversion and "revaluation of values" takes place. This process becomes the characteristic feature of the present. Coexistence of different forms of public mythologies leads to disorientation of consciousness. The need for the new horizons increases and it directs the person to searching of sense. Since reason positions in the sphere of ethics were discredited by failure of the Enlightenment project (Kudriavtseva, 2014), interest is shifted to the sphere of irrational things.

Professor Alasdair Macintyre notes the influence of a failure of the Enlightenment project on problem formation of the modern moral theory. The individual moral subject appears free from theocracy and teleology that strengthens utilitarizm positions, and rules of morals achieve the new status and associated with action of practical reason. However an attempt to find secular rational justification of moral belief of the subject was unsuccessful therefore the modern moral experience has paradoxical character (Macintyre, 2000).

\subsection{Revealing of Specifics of the Cultural Hero Image Formation}

To understand the reasons of this process, it is necessary to pay attention to features of the cultural hero image formation in the modern myth-making. Mythological meaning-making becomes the basis of this phenomenon. First, simplicity, existence of the special logical system expressed through symbols filled in various cultural realities with the significant meanings. Secondly, phenomenalism of explanatory schemes: visibility and substance in myths practically do not differ, relationships of cause and effect become simpler, a part replaces whole, surface interrelations can be taken for deep ones. Thirdly, dualism, thought moving through binary oppositions. Fourthly, panaceism. Meanings of the myth allow finding solid bases of life and instructions for practical actions in the world. Fifthly, escapism. It is flight from reality and self-identification with the fantastic Hero, Superhero. It is a mythical way to fill leisure time with positive emotions for survival in the world of daily routine. "Escapism" is called as disposal of daily occurrence, of reality, flight to the illusory world of imagination. It is escape from technical civilization, from chaos, vanity, disgrace of modern European life, pain, grief, loneliness, responsibility, death. After all any artistic image comes laden with possibility of identification of the reader or viewer with the pleasant Hero, as a way of an actual embodiment of the pleasant behavior standard in the real, not virtual, illusory world. Sixthly, schematization (moving to resolving a contradiction through triads and dyads). Schematization as a driving element of imagination plays an important role in the process of mythological meaning-making. By resolving a contradiction the phenomenon in mythical reality changes to such an extent that there is a new quality coming laden with potentially new meaning. Meaning is not just "imaginary contents attributed to any subject": if it was talked about imaginary processing of any object, there would be no need to introduce the term of meaning along with sense, sign and knowledge. The meaning comes laden with the specific content, that is it not simply our thought of a subject, but the additional thought introducing the additional contents. This additional content is introduced in human life in the process of its life-purpose orientation and self-identification. Orientation is directed to spatial-temporal modes of human existence (Where? When?), cognitive (Why? From where?), social (Who I am? What I am?) and to life-purpose projection (as a discharge of tension and harmonization of the person with the world).

Thus, mythological creativity of mass media is directed on establishment of new meanings, guided by the logical networks of thinking which are already set by antiquity, simply reconstructing them according to the changed meanings. Myth-making does not pass through stages of intuition, guesses and experiments. The myth does not look for truth, does not reflect, it states, structures, orders, clears up and by that provides rest, the happy end of all unsolved conflicts. The mode of mythological meaning-making in the modern informational world is the cultural hero. J. Campbell identifies three stages of the cultural hero personality formation: separative, consisting 
in separation of the person from the group; liminal or stage "being on the edge" and reduction (reintegrational) (Campbell, 1997). Change of social or other status consisting the main objective of initiative tests assumes escaping from the former state, destruction of the former social role. In the myth it is symbolized by literal leaving, flight and wanderings of the hero. Prior to that he hears an appeal of forces patronizing his future becoming.

Liminal stage is presented by crossing of borders (thresholds), being in unusual, transient state. Absence of the status is marked by blindness, invisibility, dirt, silence, prohibitions. Their behavior usually passive or humiliated; they have to submit implicitly to the mentors or accept unfair punishment without complaints. The hero as if in a death kingdom (especially it is indicative in case of formation of a shaman), it is "the living dead" who is facing the new birth and transformation.

Elements of the third stage of revival (transfiguration, rescue, magic flight) come to the end with apotheosis of hero's power. He gets an unusual force, magic abilities and opportunities to transfer the gained knowledge to society.

\section{Results}

\subsection{The Hero of Classical Antiquity}

So who is the hero? In the context of religious mythology the point of view of researchers of antique religion and mythology will be relevant. Let us pay attention tp the opinion of F. F. Zelinsky, the greatest European researcher of antiquity, the philologist of a silver age. He considers that heroes are "the elite among dead men who became a subject of not only family, but also public and state cult" (Zelinsky, 2010). Further the author reveals stages of becoming of the hero in the history of culture. The first stage is when deceased tsars became heroes. The second stage is a posthomeric era." There was a custom to consider people who rendered outstanding merits to a community as heroes, and they were founders of a community-for ancient communities surely people of mythical old times" (Zelinsky, 2010). The third stage is mythologization of heroes-saviors (for example, legislators) or the soldiers who were lost for the fatherland. The fourth stage is when priests, poets, well-known people become heroes. F. F. Zelinsky comes to a conclusion that the hero's cult throughout four stages was followed by a doleful cult. A pagan temple over the hero's grave was built, if it was not possible to find remains "the empty grave" (cenotaph) was constructed to which his soul was called by sacral ceremonies (Zelinsky, 2010). However sacrifices in honor of heroes differed from sacrifices to the Olympic gods. They were hold in twilight, black animals were selected for rituals, and they had chthonic character. In exchange the hero, to whom honors were done, served as an intermediary between the mythical worlds of gods, people and spirits of the underground world. Besides, it was considered that the hero transformed after death both corporally and spiritually. He became a being of super terrestrial body height and beauty with prophetic force. Further this transformation in mass consciousness divides heroes into "heroes-sanctified" and "heroes-ghouls". This way religious mythology with its binarity starts dividing the world into two parts-light and darkness, the good and evil, therefore the infernal mythology appears.

The modern myth-making in the sphere of mass culture offers a wide set of exemplars for imitating-"new heroes" and sense of the cultural hero as "carrier of the cultural benefits" moved to the sphere of honoring of an idol and to a way of identification with him in practice. The cultural hero appears in new to him meaning-making aspects-he becomes a tool of social management and mass manipulation. The image of the hero in the modern mythological meaning-making meets the need of ideals which are necessary for the person. The modern "positive" mythical hero sets the particular semantic coordinates which are reference points in spheres of human life.

Why in the XXI century in mass culture not a "superhero"-the defender of good is popular, but an image of the infernal mythical hero? As J. Stevenson writes in the research of the infernal heroes: "Vampires bewitch us with their singularity, and, bewitched, we enjoy their mysterious presence ... They become popular characters of good books and movies, then-of less good, and then-of the poorest, and then again-of very good ones. They appear in works of art and commercials. They are almost visualized, and you are already ready to distinguish them in the crowd" (Stevenson, 2011).

\subsection{Reasons of Ethical Inversion}

A natural question arises-why such infernal heroes in the present are endowed with ethically positive meaning-making loci? In our opinion, the reasons of inversion are: 1) Secular culture. In the secular world both believe and do not believe in existence of supernatural substances. Heroes are given the chance to lead self-contained life "together with people" and to try to get along with them; heroes do not speculate on religious 
subjects of rescue of their soul after death of the body or what will be after their destruction that is very difficult but possible. Professor Peter Sloterdijk in the 80-th of the XX century noted that the process of secularization led to loss of religious dreams. Motives of death are forced out and perceived purely esthetically. 2) Feminization. Change of the rights and freedoms of women allows them to express feelings more actively, to look for and fight for love, even, if darling "not like all people". 3) Demagification of the world. Therefore the infernal hero is the person living among us. People stopped to believe in heroes of fairy tales and myths. Here is how the creator of "The Vampire Diaries" and a large number of novels about the infernaln cultural heroes L. J. Smith writes about "the other world": "There is no Kingdom of Night on a map, but it exists, exists in our world. It surrounds us from all directions. This is a secret society of vampires, werewolves, sorcerers, witches and other children of darkness who live among us. They are beautiful and dangerous, they are uncontrollably tempted to people, and nobody from mortal beings can resist them. Your school teacher, your heart-felt girlfriend or am friend can be one of them" (Smith, 2010). 4) Mass culture which is built on "the hierarchy of needs". Supporters of this approach in psychology offer seven steps of such hierarchy. Each step is a solution of any fundamental problem which the person faces during the life. In order of importance we can identify: a) a survival problem (concerns all people first of all as a biosocial problem); b) population problem (birth of children, creation of a family, the material and social welfare); c) a problem of power (hierarchy of social groups, inequality); d) communication problems at the level of feelings (love, friendship, creation of the dialogue relations of cooperation, care, etc.). The first four levels also make the basis of consumer mass culture. The highest levels have a top-priority character only for the few people. They are relations on the basis of writing, statements; a problem of theoretical judgment of reality-search of reason for being, etc.; a problem of belief, intuition, and ideal. The solution of all these problems is proposed in the infernal religious mythology that makes its heroes attractive to the audience and readers. 5) In the theory of mass culture at the end of the XX century a term of "an icon of popular culture" occurs.

According to a number of authors, the most appropriate term, expressing the nature of mass culture is "icon", but not the "image" or "gestalt" designating the concept of "image" in Russian language. "This term characterizes such type of art reflection which has symbolical, unreal character, is a subject of belief, worship, but not means of reflection and knowledge of the world". (Shestakov, 1988). Thus it is emphasized that instead of icons sacred in mass culture secular icons are formed-worship to artistic images that is expressed in formation of fan groups of this or that actor or superhero. Besides, Alvin Toffler identified "central developed images injected into mass consciousness by mass media" which were necessary for standardization of necessary behavior in industrial system (Toffler, 2004) In process of acceleration of changes in society the list of images changes.

According to "Forbes" magazine, for the last 30 years box-office of movies about vampires constitutes about 1.3 billion dollars, and on average each of them brings 15 million dollars during the first week of release. The same magazine known for the ratings of the richest people of the world made also the list of the most influential vampires. In particular it consisted of E. Cullen from "Twilight", Dracula from "Van Helsing", Lestad from "Interview with the vampire" and the other Dracula-from Coppola's movie "Dracula" (Cherednichenkov, 2010). In 2014 the movie with the new version of Dracula hystory was released where the main character is presented by the family man, romantic and defender and the actor is a handsome brutal man, creating the convincing image getting into each female consciousness (http://en.wikipedia.org/wiki/Dracula_Untold).

Traditions of antiquity connected visualization with conscious or unconscious fear. The address to a visual image is presented in religious cults, magic ceremonies, remaining a part of the ritual. The well-known Canadian scientist and writer John Rolston Saul emphasizes that this function in the modern civilizationis is performed by television and cinema. Moreover, in the XX century the image becomes more real, than reality, and the content of feature films and social and political programs is built in system. This system, in fact, is the stylized public mythology which offers the heroes. Therefore, the process of creation of video images turns into the modern religious ritual (Saul, 2007), and the new type of the cultural hero is created in religious mythology-"attractive villain", the predator making good deeds.

The mythological meaning-making is mobile; it meets requirements of the present, but comprises deep meanings. Therefore the dialectic concept of a binary ethical contradiction appears before us: the good turns into the evil, the evil is represented kind and attractive. The kind cultural hero becomes boring, doubting expediency and his ability to make good deeds. The image of cynic becomes attractive, declaring "what many think on the quiet, not daring to declare it publicly" (Yankelevich, 2004). "Revaluation of values" in mass culture leads to romanticizing of negative infernal cultural heroes also, especially among female audience.

In general, it is possible to note that influence of mass media on society is increasing. Peter Sloterdijk fixes the shift to abstractionism provoked by use of telecommunication tools. It results in aggravated individualism, arty 
neoisolationism which is spread by post-modernist propoganda of life style (Sloterdijk, 2005).

\section{Discussion}

\subsection{Ethical Relativism}

The outlook of any person (including modern society) builds an ethical picture of the world as consisting of cells "positive-negative". Components of this picture are acts of this or that mythological hero which the person either approves, or condemns. His behavior in the real world is modelled through the sense of belonging to the illusory, mythological world. There are, of course, transitional shades, but for us only "pure colors" are attributing either negative attitude or positive to the world are important. Therfore, the religious mythology sets a system of particular values, focusing the person on good or the evil. To some extent it performs function of protection against destructive influence of cynicism which accompanies relativism in the sphere of morals. Mass distribution of cynicism in the modern world washes out borders between legible concepts of good and evil. Subjectivity in estimates, criteria and approaches becomes defining since a cynic recognizes morals as hypocritical means for achievement of his or her own purposes (Ojegov \& Shvedova, 1999).

Nevertheless, it is important to emphasize that for some people particular phenomenon can be estimated as evil, for others-on the contrary, it depends on position of people in society, their interests, education, etc. The same phenomenon can be in some conditions good, and in other-evil; the same things in different circumstances can be either good or evil. Despite an irony of Nietzsche who noted: "This is the same hyperbolic naivety of the person: to believe itself sense and a measure of value of things" (Nietzsche, 1910).

\subsection{Relativity and Absoluteness of Mythological Thinking}

Relativity is set by the changing life situations, absoluteness-by the archetypic models of people's thinking developed by mankind very long time ago and which are universal schemes of behavior not depending on the historical process. In the religious mythology there is transformation of the magic fairy tale at the archetypic level. Psychological approach to the fairy tale is the following: it is a product of collective human imagination. The magic fairy tale is considered from the point of view of dreams of all mankind and comprises the solution of universal problems. Heroes of fairy tales in this case are pattern dummies. Society imposes them with schemes of behavior. This approach shows personal absorption in himself by mental creation of own fairy tales on the basis of a pattern.

\subsection{Transformation of Life Purpose Forms of Behavior}

There is a transformation of life purpose forms of behavior on a trajectory from common to individual and to common. The person identifies himself with some cultural hero that allows building relationship with society correctly. This identification can be conscious like a dream of the prince charming, the fair Tsar, and can be perceived at the unconscious level like a dream "about ultramundane"-"is it a shame to love the infernal hero?" For example, in fairy tales in psychoanalytic treatment of fairy tales "prohibition, wrecking, shortage" is a formulation of a life problem, a magic assistant-a life resource, other kingdom-unconscious, future award-the created purpose. This way professional myths-fairy tales form an image of the professional, self-assured, prospering person ("The merchant-the doughty fine fellow"-the myth-fairy tale about a businessman), adaptation myths-fairy tales are created by people succeeding outwardly however having a concealed pain, a problem, excessive sensitivity, aggression, a lack of attention or love.

The fairy tale as a result of personal creation on the basis of the given archetypes, gives the description of possible forms of behavior, a way of solution of the problem, during telling a fairy tale transformation of the hero (somebody small and weak by the end of action turns into the strong, significant and self-sufficient) takes place. Therefore with all changes of the infernal cultural hero during its personal development basic values "good-evil" remain in the depth of consciousness of the individual at the level of archetypes, and the superficial qualities, visible and well presented by famous actors playing negative characters attract. In mass culture imitating becomes the key mechanism of impact on the person. Therefore it can be heard from teenagers, young people (and not only from them) that they originate from "elves", "gnomes", "orks" and so on.The main thing in imitating is appearance, brightness of an image, however the ethical depth of an image, its internal value fades from memory.

\subsection{Game as a Way of Expression of the Hero Image}

A form of expression of the hero image is the role-playing game. This phenomenon is very popular in the modern culture and, thanks to globalization, is becoming the multicultural phenomenon. In Russia there is the community of participants of role-playing games which interacts with role communities in other countries. Pisarevskaya D.B., investigating subcultures of role communities, pays attention to types of rituals and ritualized 
practics. "In the game various rituals take place: along with parade having dedicative function, there are calendar, transitional, occasional rituals. They are based on reading historical or fantasy literature and are imitated according to it. The emphasis is made on their maximal staginess" (Pisarevskaya, 2009).

The gamer can embody some images of the cultural hero in reality. As positive results we can note realization of creative potential, development of imagination of participants. Besides role-playing games promote socialization of youth and integration of a subculture into the basic culture. However there is a substitution of ethical standards against the background of the infernal hero. Formation of a positive image of the negative character promotes revolution in the system of valuable coordinates in unstable youth consciousness. The Dutch culturologist J. Huizinga noted that "it is difficult to clearly separate public unions remaining for a long time from the game sphere" (Huizinga, 2003). The youth groups submitting to particular idea of the game can easily become objects of manipulation. It involves danger of role communities without public control. To be fair it should be noted that J. Huizinga considered that game itself is out of the sphere of ethical standards, it cannot be defined as bad or good (Huizinga, 2003).

\section{Conclusion}

Steady process of aestheticization of the evil in public consciousness due to creation of new attractive images of characters propagandizing refusal of moral standards is observed. Visualization is based, generally on such principles, as: - speculation in sexuality, - violation of a taboo, - individualization (I am special), - opposition (I am not like all others), - possession of superabilities, - power expression. Violation of prohibitions, challenge, and opposition are the reference signs of cynicism. We assume that consideration of inversion of moral consciousness and identification of informational culture consumers with villains in the genre of a magic fairy tale will be perspective further. Thus, it is possible to draw a conclusion that the modern cultural hero appears as the carrier of cynical consciousness who is integrated into society from the infernal environment. The mass requirement created the corresponding demand as the representative of darkness said in "Dracula" directed by Gary Shore according to Matt Sazama and Burk Sharpless's scenario: sometimes the world does not need a hero, it sometimes needs a monster.

\section{References}

Campbell, J. (1997). The Hero with a Thousand Faces. Moscow: Valker, Refl-buk, AST.

Cherednichenko, O. (2010). Guide to lands of vampires. Moscow: Eksmo.

Dracula Untold. (2014). In Wikipedia, the free encyclopaedia. Retrieved September 24, 2014, from http://en.wikipedia.org/wiki/Dracula_Untold

Huizinga, J. (2003). Homo Ludens/Man the Player. Articles on cultural history (2nd ed.). Moscow: Ayres press.

Ivanova, E. (2013). Loneliness in Eternity: Infernal Existences of Mythical Heroes. Journal of Siberian Federal University. Humanities \& Social Sciences, 7(7), 1112-1119. Retrieved November 28, 2014, from http://elib.sfu-kras.ru/bitstream/2311/13214/3/02_Ivanova.pdf

Kirillova, N. (2005). Media culture: From a modernist style to a postmodern. Moscow: Academic Project, Technologies.

Kudriavtseva, V. (2014). Neo-cynicism of Peter Sloterdijk: A revenge of the Enlightenment? Journal of Siberian Federal University. Humanities \& Social Sciences, 8(7), 1278-1285. Retrieved November 28, 2014, from http://elib.sfu-kras.ru/bitstream/2311/13310/1/04_Kudriavtseva.pdf

MacIntyre, A. (2000). After Virtue: Researches of the theory of morals. Moscow: Academic Project; Ekaterinburg: Business book.

Nietzsche, F. (2007). Will to power. The Revaluation of All Values. Moscow: Alphabet-classics.

Ojegov, S., \& Shvedova, N. (1999). Explanatory dictionary of Russian language: 80000 words and phraseological expressions (4th ed.). Moscow: Azbukovnik.

Pisarevskaya, D. (2009). Phenomenon of a subculture of role-playing games in the modern society. The Master's thesis, Institute of ethnology and anthropology named after N. N. Miklucho-Maklaj Russian Academy of Sciences, Moscow, Russia. Retrieved November 28, 2014, from

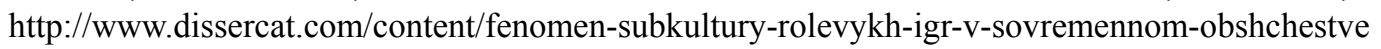

Saul, J. (2007). VOLTAIRE'S BASTARDS The Dictatorship of Reason in the West. Moscow: AST, Astrel.

Shestakov, V. (1988). Mythology of the XX century: Criticism of the theory and practice of bourgeois "mass culture". Moscow: Art. 
Sloterdijk, P. (2001). Critique of Cynical Reason. Ekaterinburg: Publishing house of the Ural University.

Sloterdijk, P. (2005) Bubbles: Spheres Volume I: Microspherology. St. Petersburg: Science.

Smith, L. (2010). Soulmate. Moscow: Eksmo.

Stevenson, J. (2011). Vampires, werewolves, witches, ghosts. Moscow: AST, Astrel.

Toffler, A. (2004). The third wave. Moscow: AST.

Yankelevich, V. (2004). Irony. Forgiveness. Moscow: Publishing house Republic.

Zelinsky, F. (2010). The history of ancient religions. Rostov-on-Don: Fenix.

\section{Copyrights}

Copyright for this article is retained by the author(s), with first publication rights granted to the journal.

This is an open-access article distributed under the terms and conditions of the Creative Commons Attribution license (http://creativecommons.org/licenses/by/3.0/). 